\title{
Journal of Biological Research
}

\section{\& Biotechnology}

Bio-Research Vol. 18 No.1; pp. 1111-1119 (2020). ISSN (print): 1596-7409; eISSN (online):9876-5432

The efficacy of aqueous leaf extracts of Hyptis suaveolens (L.) Poit and Ocimum basilicum (L.) in the control of Meloidogyne spp infecting Onion, Allium cepa (L.)

\section{sOkechalu OB, Zwalnan ND, Agaba OA and Danahap LS}

Department of Plant Science and Biotechnology, University of Jos, Plateau State.

§Corresponding author: Dr Okechalu O.B. Email: odebrains@yahoo.com

\begin{abstract}
The efficacy of aqueous leaf extracts of Hyptis suaveolens and Ocimum basilicum in the control of Meloidogyne spp infecting Allium cepa $\mathrm{L}$ (Onion) was investigated using sterile soil that was filled into polythene planting bags. Two varieties of onion (Safari and Belami) and three concentrations $(60 \mathrm{mg} / \mathrm{ml}$, $45 \mathrm{mg} / \mathrm{ml}$ and $30 \mathrm{mg} / \mathrm{ml}$ ) each of $H$. suaveolens and $O$. basilicum leaf extracts were used. Furadan at 7.7 $\mathrm{mg} / \mathrm{ml}$ was used as a positive control and the negative control was untreated. Each treatment was replicated three times in a completely randomized design (CRD). Onion raised in steam-sterilized soil were infected with 2000 juveniles of root-knot nematodes four weeks after planting. Two weeks thereafter, the different concentrations of the leaf extracts of the test plants and furadan were applied. The plants were then monitored for growth and yield parameters at harvest. Phytochemical analysis of the aqueous leaves extracts of the two plants were carried out. The result showed that growth and yield data of infected but treated onions were higher than their infected but untreated counterparts. Onions treated with $O$. basilicum at $60 \mathrm{mg} / \mathrm{ml}$ had the highest performance: plant height $(39.90 \mathrm{~cm})$, dry bulb weight $(16.70 \mathrm{~g})$ among others followed by those treated with $H$. suaveolens at $60 \mathrm{mg} / \mathrm{ml}$, plant height $(36.30 \mathrm{~cm})$, dry bulb weight $(13.20$ $\mathrm{g})$ then furadan, plant height $(36.17 \mathrm{~cm})$, dry bulb weight $(14.93 \mathrm{~g})$ while the untreated onions had the least growth and yield data, plant height $(24.40 \mathrm{~cm})$, dry bulb weight $(8.40 \mathrm{~g})$. Statistical analysis revealed that the various treatments significantly increased plant height, collar girth and leave number $(p<0.05)$ as compared to the untreated control. Variety Safari generally performed better than variety Belami. Statistical analysis also showed significant difference $(p<0.05)$ for all parameters. Phytochemical analysis showed presence of some bioactive compounds such as saponins, alkaloid, tannins among others. The study revealed nematicidal efficacy of the aqueous leaves extracts of the test plants, therefore, they can be viable alternatives to synthetic nematicides in nematode management.
\end{abstract}

Keywords: Efficacy, Nematicidal, Hyptis suaveolens, Ocimum basilicum, Allium cepa

https://dx.doi.org/10.4314/br.v18i1.6 Open Access article distributed under the terms of the Creative Commons License [CC BY-NC-ND 4.0] http://creativecommons.org/licenses/by-nc-nd/4.0.

Journal Homepage: http://www.bioresearch.com.ng.

Publisher: Faculty of Biological Sciences, University of Nigeria, Nsukka, Nigeria. 


\section{INTRODUCTION}

Onion (Allium cepa L.) is one of the major bulb vegetable crops of the world (Roopa et al., 2014). The World onion production is steadily increasing so that it is now the second most important horticultural crop after tomatoes (Bankole et al., 2004). Onion is one of the most important and familiar spice crops throughout the world. It's nutritional and medicinal values such as sugar, vitamins, minerals, electrolytes, protein and dietary fibre cannot be over emphasized (Onuorah and Ifeanyi, 2015). Allium cepa is also an important vegetable crop in Nigeria based on consumption and economic values to farmers (Ole et al., 2004).

Globally, annual losses resulting from infestations caused by plant parasitic nematodes are huge. In economic terms, nematodes cause an estimated loss of about $\$ 157$ billion annually to world agriculture (Singh et al., 2015). The rootknot nematodes, Meloidogyne spp has been reported as the most important plant parasitic nematodes since they infest majority of the economically important plant species in the world (Abad et al., 2008, Ekpenyong et al., 2016).

Medicinal plants have been identified and used throughout human history. Plants have the ability to synthesize a wide variety of chemical compounds that are used to perform important biological functions. They defend against attack from predators such as insects, fungi, nematode and herbivorous mammals. At least 12,000 of such compounds have been isolated so far; a number estimated to be less than $10 \%$ of the total (Tapsell et al., 2006). These botanical extracts have been found to contain phytochemicals such as alkaloids, tannins, saponins, flavonoids, diterpenes, glucosinolates, acetylenes and thienyls (Chitwood, 2002). These phytochemicals are effective against plant parasitic nematodes (Khan et al., 2017, Singh, 2015). Some members of the family Lamiaceace such as Hyptis suaveolens (L.) and Ocimium basilicum (L.) have been reported to be rich in phytochemicals such as flavonoids, alkaloids, carbohydrates, tannins, saponins and phenol hence potentially nematicidal (Devi, 2015, Khair-ul-Bariyah, et al., 2012). Farmers generally have relied on the use of synthetic nematicides over the years and they are currently the most effective means of pest control. This has resulted to its excessive and unsafe usage (Taniwiryono, et al., 2007).

Indiscriminate use of synthetic nematicides for the control of nematodes leads to phytotoxicity, environmental pollution, nematodes resistance and affects many other non-target organisms. On the other hand, its unsafe usage may result in poisoning of humans especially in developing countries like Nigeria (Ojo, 2016, Anwar et al., 2009). To this effect, it is of importance to find alternative control strategies which are as effective as synthetic nematicides, environmentally friendly and relatively available at low cost (Ekpenyong et al., 2016). It is against this backdrop that this study was done with the aim of determining the efficacy of $H$. suaveolens and $O$. basilicum in the control of Meloidogyne spp infecting onions. The specific objectives were i) To determine the nematocidal effects of different concentrations of extracts of $H$. suaveolens and $O$. basilicum on Meloidogyne species infecting onion cultivars. ii) To determine the effect of the treatment on the growth and yield of Onion and iii) To evaluate the proximate composition of onions bulbs from all treatments

\section{MATERIALS AND METHODS}

\section{Experimental Site and Soil sterilization.}

The study was conducted at the Botanical Nursery Unit of the Federal College of Forestry, Jos, Plateau state. The soil used for this investigation was heat sterilized at $65{ }^{\circ} \mathrm{C}$ for 90 minutes using electric soil sterilizer and allowed to cool before packing into perforated polythene planting bags.

\section{Source of onion Seeds}

Seeds of onion varieties Safari and Belami used for this study were obtained from Agric Tropic Limited (Technism Office, Jos branch, Plateau State, Nigeria).

\section{Source of Inoculum and Extraction of Root Knot Nematodes}

Tomato plants were sampled from different farms within Jos and environs and examined for the presence of galls on their roots (Gowen et al., 2005). Roots showing the presence of galls were brought to the laboratory for extraction of nematodes. The modified Baermann funnel method of nematode extraction (Southey,1970) was used for the nematode extraction. The galls from the roots were placed in Petri dishes, 2 pipette drops of distilled water was added to moisten them, then teased apart. The root samples and distilled water in the Petri dishes were poured into a Baermann funnel with a short 
piece of rubber tubing attached to the stem. A test-tube filled with water was then attached to the end of the rubber tube and made airtight at both the point of attachment with the funnel and the test-tube using masking tape. The funnel was lined with a thin layer of cotton wool and supported in an upright position. The root samples in the funnel were then watered to prevent them from drying and to allow for free movement of the nematodes. Twenty (20) sets of the Modified Baermann funnel were prepared. The set-ups were allowed to stand for 48 hours. Nematode juveniles that were hatched in the water pass through the cotton wool and were collected at the bottom of the test-tubes. Nematodes were identified to species level based on morphological features as described by Hooper et al., (2005) and the University of Nebraska Lincoln nematode identification website available at http://nematode.unl.edu/konzlistbutt.htm

Identification was based on adult female nematodes. Nematode population estimation was done by counting the number of active juveniles in $1 \mathrm{ml}$ of homogenized suspension of the inoculum on a nematode counting dish using a binocular research microscope at X40 magnifications. The enumeration was done 5 times and the average nematode count was determined. One (1) $\mathrm{ml}$ of the suspension was found to contain 125 juveniles of nematodes.

\section{Preparation of Plant Extracts}

Fresh leaves of Hyptis suaveolens and Ocimium basilicum were collected from Maza, Rusol and Angwa Rukuba villages in Jos and air-dried before they were blended to powder using VTCL Speedo Mixer Grinder. The pulverized leaves were soaked in water for 72 hours and filtered to remove the residue. The filtrate was concentrated to powder by boiling using a hot plate at $100^{\circ} \mathrm{C}$. The different concentrations of the plants were then prepared by dissolving variable weights_of the powdered residue (using digital weighing balance) in distilled water as follows:

$0.30 \mathrm{~g}$ of extract in $10 \mathrm{ml}$ of water $=0.030 \mathrm{~g} / \mathrm{ml}$ $=30 \mathrm{mg} / \mathrm{ml} ; 0.45 \mathrm{~g}$ of extract in $10 \mathrm{ml}$ of water $=$ $0.045 \mathrm{~g} / \mathrm{ml}=45 \mathrm{mg} / \mathrm{ml} ; 0.60 \mathrm{~g}$ of extract in $10 \mathrm{ml}$ of water $=0.060 \mathrm{~g} / \mathrm{ml}=60 \mathrm{mg} / \mathrm{ml}$

\section{Phytochemical Analysis of $\boldsymbol{H}$. suaveolens and $O$. basilicum leave extracts}

The phytochemical screening for qualitative detection of flavonoids, tannins, alkaloids, saponins, phlobatannin and cardiac glycosides among others were performed on the extracts of both plants as described by AOAC (2007).

\section{Experimental Design.}

The experiment was laid out in a completely randomized design (CRD) in an open field using poly bags with 2 onion varieties, 2 plant extracts with the extracts applied in 3 different concentrations $(30,45$ and $60 \mathrm{mg} / \mathrm{ml})$ furadan (standard nematicide) and a negative control (inoculated but untreated). All treatments were replicated three (3) times.

\section{Pot experiments}

Onion seeds were broadcasted on sterile soil in containers and allowed to grow, then maintained in the nursery for six weeks (42 days) after germination. Apparently healthy seedlings were then transplanted into 48 polythene bags (one per polythene bag) filled with sterile soil. Four weeks after transplanting, the plants were inoculated using the modified method of Hagop et al. (2012). This was done by pouring $16 \mathrm{ml}$ of the nematode suspension containing 2,000 nematode juveniles into holes around the root of seedlings and 2 weeks afterwards $30 \mathrm{mg} / \mathrm{ml}, 45 \mathrm{mg} / \mathrm{ml}$ and 60 $\mathrm{mg} / \mathrm{ml}$ of extracts were added to pots separately. Furadan at an application rate of $4 \mathrm{~kg} / \mathrm{ha}$ which was equivalent to $7.7 \mathrm{mg} / \mathrm{ml}$ based on the area of poly bags used for this research was positive control while untreated pots served as negative control. Growth parameters or agronomic characters per plant such as shoot length, root length, root weight and root galls were collected and recorded at harvest. Number of galls per plant was determined and recorded. Also gall indices were calculated on a scale of $0-5$ and Resistant Ratings determined as described by Taylor and Sasser (1978), where: 0 galls = immune, $1-2$ galls $=1$ (Highly Resistant), 3-9 galls $=2$ (Moderately Resistant), $10-30$ galls $=3$ (Moderately Susceptible), $31-100$ galls $=4$ (Susceptible), 100 and above galls $=5$ (Highly susceptible)

\section{Data Analysis}

All data generated were analyzed using Statistical Package for Social Sciences (SPSS Statistics version 23). The two-way analysis of variance (ANOVA) at 0.05 level of probability was the analytical used while Means were separated using the Least Significant Difference (LSD) test. 


\section{RESULTS}

The root-knot nematodes species were found to be Meloidogyne incognita and Meloidogye Javanica.

\section{Phytochemical Screening}

The phytochemicals present in the leaf extracts of $H$. suaveolens and $O$. basilicum included flavonoids, alkaloids, carbohydrates, tannins, saponins, phenol and glycosides (Table 1).

\section{Effect of Treatments on Growth Parameters}

The result revealed that onion height increased with increase in concentration of the extracts. The highest shoot height was recorded at concentration $60 \mathrm{mg} / \mathrm{ml}$ for both extracts i.e 39.90 $\mathrm{cm}$ and $36.17 \mathrm{~cm}$ for $O$. basilicum and $H$. suaveolens respectively. Generally, $O$. basilicum extract accounted for higher onion height than H.suaveolens extract across the various concentrations (Table 2). All treated plants had higher plant height than their untreated controls. Statistical analysis revealed that, the various treatments significantly increased onion height $(P<0.05)$ as compared to the untreated control (Table 2). Among inoculated and treated onions as well as untreated ones, variety Safari had the highest plant height (36.23 and 24.0 ) respectively (Table 2). Number of leaves per plant increased with increase in concentration of extracts for both plants.Generally, onion treated with $H$. suaveolens_extract at $60 \mathrm{mg} / \mathrm{ml}$ had the highest number of leaves (8.33) as compared with all other treatments. Number of leaves were higher for variety Safari than Belami. Statistical analysis revealed that the number of leaves produced by onion plants treated with the extracts were significantly $(p<0.05)$ higher than those produced by the untreated controls (Table 3 ).

Table 1: Phytochemical constituents of $H$. suaveolens and $O$. basilicum aqueous leaf extracts

\begin{tabular}{lll}
\hline Phytochemical Constituent & H.suaveolens & O.basilicum \\
\hline & & ++ \\
Flavonoids & +++ & + \\
Tannins & ++ & +++ \\
Saponins & + & - \\
Phenol & + & ++ \\
Glycoside & + & + \\
Carbohydrate & - & +++ \\
Alkaloid & Key: - = not present, ++ = present in moderate concentration (amount), +++ = present in high concentration (amount)
\end{tabular}


Table 2: Effect of the different concentrations of test plants extracts and the controls on plant height $(\mathrm{cm})$ of onion infected with nematodes

\begin{tabular}{|c|c|c|c|c|}
\hline \multirow[t]{2}{*}{ Treatment } & \multirow[t]{2}{*}{ Concentration $(\mathrm{mg} / \mathrm{ml})$} & \multicolumn{2}{|c|}{ Varieties } & \multirow[t]{2}{*}{ LSD $_{0.05}$} \\
\hline & & Safari & Belami & \\
\hline \multirow[t]{3}{*}{ H. suaveolens } & 30 & 29.50 & 28.50 & 0.435 \\
\hline & 45 & 31.07 & 32.23 & \\
\hline & 60 & 36.23 & 34.67 & \\
\hline \multirow{3}{*}{ O. basilicum } & 30 & 32.50 & 33.00 & \\
\hline & 45 & 32.37 & 31.83 & \\
\hline & 60 & 35.00 & 39.90 & \\
\hline Furadan2 & & 34.50 & 36.17 & \\
\hline Untreated & & 24.00 & 23.80 & \\
\hline $\mathrm{LSD}_{0.05}$ & 0.163 & & & \\
\hline
\end{tabular}

Table 3: Effect of the Different Concentrations of Test Plants Extracts and the Controls on number of leaves of Onion infected with nematodes.

\begin{tabular}{|c|c|c|c|c|}
\hline \multirow[t]{2}{*}{ Treatment } & \multirow[t]{2}{*}{ Concentration $(\mathrm{mg} / \mathrm{ml})$} & \multicolumn{2}{|c|}{ Varieties } & \multirow[t]{2}{*}{$\mathrm{LSD}_{0.05}$} \\
\hline & & Safari & Belami & \\
\hline \multirow[t]{3}{*}{ H. suaveolens } & 60 & 8.33 & 8.00 & \\
\hline & 45 & 8.33 & 8.00 & 0.247 \\
\hline & 30 & 7.00 & 7.67 & \\
\hline \multirow[t]{3}{*}{ O. basilicum } & 60 & 7.67 & 7.33 & \\
\hline & 45 & 7.67 & 7.00 & \\
\hline & 30 & 7.67 & 7.67 & \\
\hline Furadan & 2 & 8.00 & 7.00 & \\
\hline Untreated & & 6.70 & 6.67 & \\
\hline $\mathrm{LSD}_{0.05}$ & 0.177 & & & \\
\hline
\end{tabular}

Collar girth increased with increase in concentration of extracts for both plants. Onion plants treated with $O$. basilicum extract at 60 $\mathrm{mg} / \mathrm{ml}$ had higher collar girth $(4.73 \mathrm{~cm})$ than all others (Table 4). The treated plants had higher collar girth than their untreated counterparts. Statistically, the treatments significantly $(P<0.05)$ influenced collar girth as compared with the untreated control (Table 4).

\section{Effect of Treatments on yield data}

The fresh and dry weights of onion showed that the weight increased with concentration of extracts for both plants.
Onion treated with $O$. basilicum at $60 \mathrm{mg} / \mathrm{ml}$ had the highest dry weight $(16.70 \mathrm{~g})$, followed by those treated with Furadan $(14.93 \mathrm{~g})$, then $\mathrm{H}$. suaveolens at $60 \mathrm{mg} / \mathrm{ml}(13.20 \mathrm{~g})$ while the untreated control had the least $(8.40 \mathrm{~g})$. Variety Safari had higher fresh and dry weight than variety Belami (Table 5)

\section{Effects of treatments on Number of Galls, Gall Index and Resistant Rating}

Number of galls was highest in untreated onions (18.33) followed by onions treated with $30 \mathrm{mg} / \mathrm{ml}$ (2.0) then $45 \mathrm{mg} / \mathrm{ml}$ (1.33) while onions 
Table 4: Effect of the different concentrations of test plants extracts and the controls on collar girth $(\mathrm{cm})$ of onion infected with nematodes

\begin{tabular}{|c|c|c|c|c|}
\hline \multirow{2}{*}{ Treatment } & \multirow{2}{*}{ Concentration $(\mathrm{mg} / \mathrm{ml})$} & \multicolumn{2}{|c|}{ Varieties } & \multirow{2}{*}{$\mathrm{LSD}_{0.05}$} \\
\hline & & Safari & Belami & \\
\hline \multirow[t]{3}{*}{ H. suaveolens } & 60 & 3.56 & 3.40 & \\
\hline & 45 & 3.32 & 3.20 & 0.658 \\
\hline & 30 & 3.03 & 3.00 & \\
\hline \multirow[t]{3}{*}{ O. basilicum } & 60 & 4.73 & 3.60 & \\
\hline & 45 & 3.27 & 3.23 & \\
\hline & 30 & 3.17 & 3.17 & \\
\hline Furadan2 & & 3.10 & 3.60 & \\
\hline Untreated & & 2.50 & 2.87 & \\
\hline LSD & 0.383 & & & \\
\hline
\end{tabular}

Table 5: Effect of concentrations of test plants extracts and the controls on fresh weight $(\mathrm{g})$ and dry weight (g) of the two varieties of onion



treated with concentration $60 \mathrm{mg} / \mathrm{ml}$ had the least number of galls (0.33). Onions treated with $O$. basilicum extract at $30 \mathrm{mg} / \mathrm{ml}$ had higher number of galls (3.33) than those treated with $H$. suaveolens extract at $30 \mathrm{mg} / \mathrm{ml}(2.00)$. Variety Belami had higher number of galls across treatments except among the untreated Onions where Variety Safari had 18.33 while Variety Belami had 14.00 galls (Table 6). Resistance rating showed variation in the plants' response to the varying treatments. The untreated plants were moderately susceptible with gall index of three (3). Belami variety treated with $O$. basilicum at concentration $30 \mathrm{mg} / \mathrm{ml}$ was also moderately susceptible with gall index of 3.33. $H$. suaveolens treated at concentration $30 \mathrm{mg} / \mathrm{ml}$ was moderately resistant with gall index of 2 . All other plants were highly resistant with gall index of one (1) except Belami variety treated with $O$. basilicum extract at concentration $45 \mathrm{mg} / \mathrm{ml}$ which was moderately resistant with gall index of 2 (Table 6) 
Table 6: Effects of the varying concentrations of $H$. sauveolens and $O$. basilicum on resistance rating of onion cultivars.

\begin{tabular}{|c|c|c|c|c|c|}
\hline Variety & Treatment & $\begin{array}{l}\text { Concentration } \\
(\mathrm{mg} / \mathrm{ml})\end{array}$ & Number of Galls & Gall index & Level of Resistance \\
\hline \multirow[t]{8}{*}{ Safari } & H. sauveolens & 30 & 1.67 & 2 & Moderately resistant \\
\hline & & 45 & 1.00 & 1 & Highly resistant \\
\hline & & 60 & 0.33 & 1 & Highly resistant \\
\hline & O. bacilicum & 30 & 1.67 & 2 & moderately resistant \\
\hline & & 45 & 1.33 & 1 & Highly resistant \\
\hline & & 60 & 0.33 & 1 & Highly resistant \\
\hline & Furadan & & 1.33 & 1 & Highly resistant \\
\hline & Untreated & & 18.33 & 3 & Moderately susceptible \\
\hline \multirow[t]{8}{*}{ Belami } & H. sauveolens & 30 & 2.0 & 2 & moderately resistant \\
\hline & & 45 & 1.33 & 1 & Highly resistant \\
\hline & & 60 & 0.67 & 1 & Highly resistant \\
\hline & O. basilicum & 30 & 3.33 & 3 & Moderately susceptible \\
\hline & & 45 & 2.33 & 2 & moderately resistant \\
\hline & & 60 & 1.00 & 1 & Highly resistant \\
\hline & Furadan & & 1.00 & 1 & Highly resistant \\
\hline & Untreated & & 14.00 & 3 & Moderately susceptible \\
\hline
\end{tabular}

\section{Discussion}

The phytochemical analysis revealed that the leaves extracts of $H$. suaveolens and $O$. basilicum contain some bioactive constituents such as flavonoids, alkaloids, carbohydrates, tannins and saponins. The presence of these phytochemicals in the extracts of the two plants may have been responsible for the observed improved growth and yield of treated onion cultivars as compared to their untreated controls. Khan et al. (2017) reported the presence of alkaloids, flavonoids, tannins and saponins in weeds from India and further said they could be responsible for the observed mortality of Meloidogyne population in vitro. Chitwood (2002) also reported that bioactive compounds such as Alkaloid, Tannin, Saponin, Flavonoid and Steroid among others have nematicidal activity. These, therefore, explains the nematicidal activities of the leaf extracts in the present study.Growth and yield data of infected onions treated with extracts of $H$. suaveolens and $O$. basilicum increased as compared to their untreated controls. This is indicative of the nematocidal potential of the extracts which may have ameliorated the effects of the nematodes hence the improved growth and yield in treated plants. This finding is similar to that of Khan et al., (2019) who reported that nematode infestation led to stunted growth and treatment with extract led to increase in growth and yield. They attributed their findings to the presence of the bioactive components in the extracts that suppressed the nematodes' activities. They also said higher performance of extract treated plants compared to the untreated controls may have been due to increased organic matter content to the plant. Singh (2015) reported similar findings and further said that bioactive constituents in plants extracts used as treatments accounted for the improved yield of nematode infected plants compared to their untreated counterparts. Growth and yield of extract treated onions increased with application rate. This may mean that more bioactive components with nematocidal activity were available in the soil. It could also be that more organic matter was available to the onions to improve their performance. Singh (2015) while evaluating nematocidal potency of botanical biopesticides on Meloidogyne incognita infecting 
chickpea reported that the efficacy of the biopesticides increased with application rate.

$M$. incognita and $M$. javanica were the species of root knot nematodes identified in this study. It is very likely that these species are more adapted to the Jos soil environment than other species of the root knot nematodes Yao et al. (2017) reported that $M$. incognita and $M$. javanica are the most dominant root knot nematodes species in Nigeria. Olowe (2004) working on distribution of root knot nematodes in cowpea fields in Nigeria also reported these two species as the most prevalent.

Number of galls and gall index indicated variability in the variety and the various treatments. The improved resistance ratings of treated plants over untreated plants suggests that the treatment improved the onions response to the nematode infection and that the extract of the test plants must have been toxic to juveniles of nematodes thus reducing nematode population density as well as galling. Similar results have been reported by other workers (Zhou et al. 2012, Oka et al., 2007). Variation among the varieties may be due to inherent factors. Onions that were inoculated and un-amended performed poorly, this was expected. It implies that the un-amended onions were readily attacked by nematodes as evident by the highest number of galls and the least growth and yield data. This finding is in line with the report of Khan et al., (2019) who said nematode infection of plants led to stunted growth.

\section{Conclusion}

The findings of this study have shown that the leaf extracts of $H$. suaveolens and $O$. basilicum have nematicidal activities. The $60 \mathrm{mg} / \mathrm{ml}$ concentration outperformed the standard nematicides, furadan. It is therefore, concluded that the plant extracts are viable alternatives to chemical nematicides in the control of root-knot nematodes and are therefore recommended for use as bio-pesticides.

\section{Conflict of interest}

Authors have no conflict of interest to declare.

\section{REFERENCES}

Abad, P., Gouzy J., Aury, J.M., Castagnonesereno, P., Danchin, E.G., Deleury, E.,Perfus-Barbeoch L., Anthouard V.,
Artiguenave F., and Blok V.C., (2008). Genome sequence of the metazoan plant parasitic nematode Meloidogyme incognita. Nature Biotechnology. 26: 909-915.

Anwar, A., Groom, M., Sadler-Bridge, D. (2009). Garlic: From natures ancient food to nematicide. A review. Pesticide News 84: 18- 20.

Association of Official Analytical Chemists, A. O. A. C. (2007). Official Methods of Analysis, $18^{\text {th }}$ Edition, Wilson Boulevard Publishers: Arlington, Virginia, USA.

Bankole, S.A., Ogunsanwo B.M., and Mabekoje O.O., (2004). Natural occurrence of moulds and aflatoxin b1 in melon seeds from markets in Nigeria. Food Chemistry and Toxicology.42:1309-1314.

Chitwood, D.J (2002). Phytochemical based strategies for nematode control. Annual Review of Phytopathology.40:221249.

Devi, P.M., (2015). A review on the pharmacology and phytochemistry of folklore medicinal plant Hyptis Suaveolens (L.) Poit. International Journal of Basic, Applied and Innovative Research 4(4): 108 - 117.

Ekpenyong, E.P., Ononuju, C.C., Orikara, C.C., and Ikwunagu, E.A., (2016). Nematocidal potential of three plant materials against root-knot nematode (Meloidogyne incognita) infestation on tomato (Solanum lycopersicum). International Journal of Life Sciences, 4(1):22-28.

Gowen S.R., Patrick Q., and Fogain R. (2005). Nematode parasite of bananas and plantains. Plant parasitic Nematodes in Subtropical and Tropical Agriculture, 2:611-643.

Hagop, S., Atamian, P.R. and Isgouhi, K., (2012). High and low through put screens with root-knot nematodes, Meloidogyne spp. Journal of Visualized Experiments, 61:61- 64.

Hooper, D.J., Hallmann, J. and Subbotin, S. (2005). Methods for extraction, processing and detection of plant and soil nematodes. In: Luc, M., Sikora, R.A. and Bridge (Eds.). Plant Parasitic Nematodes in Subtropical and Tropical Agriculture, 2nd Edition (Pp 53-86). Wallingford.

Khair-ul-Bariyah, S., Ahmed, D., and Ikram, M. (2012). Ocimum bacilicum: A review of phytochemical and pharmacological studies. Pakistan Journal of Chemistry 2(2)75-85. 
Khan, R., Hussain, S, Khan, A., Ullah, S., Rashid, $\mathrm{M}$, and Siddique I. (2019) Phytochemical management of root knot nematodes (Meloidogyne incognita) by Artemisia spp in tomato. Brazilian Journal of Biology 10:590 - 600 .

Khan, A., Asif, M, Tariq, M., and Rehman, B. (2017) Phytochemical investigation of nematostatic and nematocidal potential of weed extracts against Meloidogyne incognita In vitro. Asian Journal of Biological Sciences 10 (2):38- - 46.

Ojo, J. K. (2016) Pesticides use and health in Nigeria. Ife Journal of Science 18 (4):111.

Oka, Y., Tkachi, N, Shuker, S., and Yerumiyahu, U., (2007) Enhanced Nematocidal activity of organic and inorganic ammonia-releasing amendments by Azadirachta indica Extracts. Journal of Nematology 39:9-16.

Ole, H Torben, L., Christensen, L. P, Nazmul, H.M., and Shakuntatala, H.T., (2004). Concentration of Iron, Calcium, Zinc and B. carotene in commonly consumed vegetables in Bangladesh. Journal of Food Composition and Anlaysis. 17:587595.

Olowe, T., (2004). Occurrence and distribution of Meloidogyne spp in cowpea growing arears in Nigeria. Nematology.6(6):811817.

Onuorah, S., and Ifeanyi, O., (2015). Fungi associated with the deterioration of postharvest onion bulbs sold in some markets in Awka, Nigeria Bioengineering and Bioscience 3(5): 90-94.

Roopa, V.N., Suvarna, V.C., and Natesh, N. (2014). Antimicrobial activity of plant extract against post-harvest spoilage of onion. International Journal of Current Microbiology and Applied Science. 3 (55):388-394.

Singh, S., B. Singh and Singh, A.P. (2015). Nematodes: A threat to sustainability of Agriculture. Procedia Environmental Sciences, 29: 215-216.
Singh, R. (2015). Evaluation of nematicidal potency of botanical biopesticides in combination with triazophos against root-knot nematode, Meloidogyne incognita infestation on chickpea, Cicer arietinum L. International Journal of Applied. \& Natural Science, 4 (3): 75-82.

Southey, J. F. (1970). Laboratory Methods for Work with Plant and Soil Nematodes.Technical Bulletin 2 Her Majesty's Stationary office, London. 148pp.

Taniwiryono, W.D., Brink, P.V., Rietjens,I.M. and Murk, A.J., (2007). A case study in Bangka Island, Indonesian on the habits and consequences of pesticides use in black peppe plantations. Journal of Environmental Toxicology. 22(4): 405414.

Tapsell, L.C., Hemphill, I., and Cobiac, L., (2006). "health benefits of herbs, and spices: the past, the present, the future". Medical Journal of Australia. 185.122132.

Taylor, A.L., and Sasser, J.N., (1978). "Biology, identification and control of plant - knot Nematode, Meliodogyne "North California State University Graphics Pp 22. University of Nebraska Lincoln nematode identification website (http://nematode.unl.edu/konzlistbutt.ht $\mathrm{m})$.

Yao, A., K., Gerrit, K. and Wim, B., (2017). Diversities of root-knot nematodes associated with tubers of yam established using isosyme analysis and mitochondrial DNA-based

identification. Journal of Nematology 49(2): 177-188.

Zhou, L., Wang, J., Wang, K., Xu J., Zhao, J., Shan T. and Luo C., (2012). Secondary metabolites with antinematodal activity from higher plants: In studies in natural products chemistry Volume 37 . Bioactive natural products, Atta-ur-Rahman (eds.). p.67-114. Elsevier, Oxford, UK 